\title{
Grundtvigs betydning for samfundet
}

\author{
Jes Fabricius Møller
}

På tre udvalgte områder, velfærdsstaten, højskolebevægelsen og forfatningen, søger denne artikel at kortlægge Grundtvigs betydning. Forskningen har vist, at det er en sen tradition, der knytter Grundtvigs navn til den moderne velfærdsstat, og selv om Grundtvigs stilling til ikke mindst Grundlovens forsørgelsesparagraf kunne lede til den tanke, at han var økonomisk liberalist, kan man med lige stor ret hævde, at han blot ønskede at bevare enevældens principper for fattigforsørgelse. Grundtvigs betydning for de første højskoler var begrænset. Først i 1850erne kom en fastere forbindelse i stand mellem Grundtvig og folkehøjskolerne. At Grundtvig var tilhænger af enevælden er velkendt, men alligevel beskrives han også ofte som proto-demokrat i den liberale tradition fra John Locke. Her argumenteres der for, at Grundtvig helt frem til de første år som rigsdagsmand var monarkist i den konservative tradition fra Thomas Hobbes. ${ }^{1}$

\section{Indledning}

Man støder ofte på den vurdering, at Grundtvigs betydning næppe kan overvurderes. ${ }^{2}$ Det er hensigten med de følgende sider at stille spørgsmålet,

\footnotetext{
${ }^{1}$ Bidraget er en bearbejdet udgave af Jes Fabricius Møllers tiltrædelsesforelæsning som professor MSO ved Grundtvig Centeret den 23. februar 2015 ved Aarhus Universitet.

${ }^{2}$ Eksempelvis: "Ifølge [...] Ove Kaj Pedersen, er det vanskeligt at overvurdere Grundtvigs betydning som samfundsbygger." Information 10. januar 2011, "Hans betydning for sin egen tid og inspirationen fra hans indsats siden hen kan næppe overvurderes." Gyldendals åbne encyklopædi, "Hans betydning for sin egen tid og inspirationen fra hans indsats siden hen kan næppe overvurderes." Massoud Fouroozandeh, kristendom.dk, 11. okt. 2010. Se også Fransson 2003, 126.
} 
om der ikke netop har fundet en overvurdering af Grundtvigs betydning eller virkning sted? Formålet er ikke at benægte, at Grundtvig havde og har betydning og virkning for samfundet, men at kvalificere forstålsen af Grundtvigs betydning eller virkning for samfundet.

Som bl.a. Thorstein Balle peger på, er der forskellige mulige betydninger af begrebet "Grundtvig". Balle beskæftiger sig med den sene virkningshistorie, hvor Grundtvig har antaget skikkelse af mytologisk figur (Balle 2014), men jeg vil her tage udgangspunkt i den biografiske skikkelse N.F.S. Grundtvig, set ud fra et klassisk, historisk aktørperspektiv, forstået i modsætning til f.eks. en strukturalistisk eller poststrukturalistisk forståelse af individets og subjektets rolle i den historiske proces. Her er heller ikke tale om virkningshistorie i gadamersk forstand. Det er altså et både altmodisch og enkelt spørgsmål, der her stilles: Hvad gjorde og sagde han selv? Man kunne kalde det et fornæret perspektiv at anlægge, fordi det udelukker den indirekte påvirkning eller betydning, der ubetvivleligt er udgået fra Grundtvig til så mange mennesker, men denne bevidst anlagte perspektivindskrænkning skal i udgangspunktet tjene til at slå fast, hvad vi med rette kan sige, hvis vi med begrebet "Grundtvig" mener den biografiske N.F.S. Grundtvig som forfatter og politiker.

Af praktiske og omfangsmæssige hensyn begrænses undersøgelsen til profanhistoriske spørgsmål, således at kirkelige og teologiske spørgsmål lades ude af betragtning. Nærmere bestemt vil Grundtvigs forhold til velfærdsstaten, højskolen og demokratiet/forfatningen blive behandlet, nogle af de områder, hvor Grundtvigs navn ofte bliver fremhævet. Andre felter som f.eks. andelsbevægelsen eller grundskolen kunne også være blevet inddraget. Især andelsbevægelsen er et godt eksempel på et område, hvor Grundtvig ikke havde nogen direkte indflydelse i den betydning af ordet, som anlægges her. Med hensyn til grundskolen henvises til Thorstein Balles undersøgelse i Grundtvig-Studier 2014 (Balle 2014). Mine konklusioner kan endvidere kun i begrænset omfang gøre krav på originalitet, idet de for det meste bygger på velkendt og til dels endda ret gammel forskning, men jeg håber, at de kan kvalificere den fortsatte diskussion, når spørgsmålet således sættes lidt på spidsen. 


\section{Virkning og betydning}

Hvis man skal udrede, hvad Grundtvig betød, hvilken virkning han faktisk havde, må man gå tilbage til manden selv, altså tage den biografiske realitet N.F.S. Grundtvig alvorligt. Hvad sagde, skrev og gjorde han egentlig, som havde konstaterbar virkning? Det vil sige, at det skal være ideer, der kan omsættes til handling i samfundsmæssig forstand f.eks. i lovgivning eller en institution. Dermed udelukker jeg den intellektuelle eller åndelige virknings- eller receptionshistoriske påvirkning, altså at hans tanker påvirkede andres tanker, f.eks. at Grundtvigs syn på den apostolske trosbekendelse blev overtaget af hans tilhængere. Det drejer sig altså ikke om Grundtvig som intellektuel, men hans betydning for samfundet. Denne distinktion mellem den samfundsmæssige og intellektuelle påvirkning kræver naturligvis at blive kvalificeret. Den bygger på forskellen - og sammenhængen - mellem idé og handling. Virkning defineres her foreløbigt som en idé, der omsættes til handling.

Når man ser på ideers omsætning til handling, er det imidlertid ikke nok at konstatere, at en idé, der på et tidspunkt er virkeliggjort, forekommer et sted i Grundtvigs forfatterskab, for at fastslå, at Grundtvig er ophavsmand til samme idés virkeliggørelse. Mellemregningerne må med. For at en person kan siges at have haft indflydelse på et samfund, må følgende forudsætninger være på plads:

1. Det skal kunne godtgøres, at idéen i et eller andet omfang stammer fra denne person.

2. Ideen skal være operationalisérbar, altså omsættelig i handling. Jo mere generel og abstrakt en idé er, desto vanskeligere er den at konkretisere og omsætte i handling. "Samfundet skal være retfærdigt" er i sig selv en vældig god ambition, men den er kun omsættelig til handling, hvis det specificeres, hvad man mener.

3. Idéen skal være identificérbar. Generelle idéer kan være rigtig gode jf. kriterium 2 - men i så fald er de sjældent særligt originale, jf. det første kriterium. Nævn f.eks. den samfundsteoretiker, der er modstander af udsagnet "Samfundet skal være retfærdigt".

4. Overførsel af idé fra ophavsmand til handlende individer skal bevises eller i det mindste sandsynliggøres. Tradering af idéer er ikke en proces, der normalt lader sig dokumentere med nogen særlig præcision. 
Nogle systemer - f.eks. videnskaben og patentlovgivningen - har formaliseret identifikationen, viderebringelsen og brugen af den originale idé. Men på andre felter, som f.eks. i politik, foretages udvekslingen af idéer på et marked præget af stor uigennemsigtighed og ringe respekt for ophavsrettigheder. ${ }^{3}$

5. Idéen skal ses virkeliggjort af dem, der har overtaget den. I samfundsmæssig henseende vil virkeliggørelse typisk bestå i, at idéen omsættes $i$ en eller anden form for klart identificérbar handling: institutionsgrundlæggelse, lovgivning, kulturel bevægelse osv.

6. Virkeliggørelsen skal være af betydning for samfundet, det vil sige, at den skal påvirke en større gruppe af mennesker over et vist tidsrum. ${ }^{4}$

Der skal altså være fuld gennemsigtighed i hele processen fra ord til handling, for at man entydigt kan tale om, at en given person har haft betydning eller virkning. Her tages der ikke stilling til det, som man kan kalde den negative indflydelse, altså at en fremtrædende stilling i samfundsdebatten sådan som Grundtvig indtog især sent i sit liv, kan medføre, at ting $i k k e$ gennemføres. En dokumentation af den slags indflydelse forudsætter en velunderbygget kontrafaktisk vurdering af, hvad der ville have været sandsynligt, hvis ikke Grundtvig havde gjort sin indflydelse gældende. Det er en legitim og interessant, men ret kompliceret beregning at foretage, og den ligger uden for rammerne af dette forsøg.

For Grundtvigs vedkommende er den positive betydning eller virkning ud fra de seks ovenstående kriterier klarest dokumenteret i den kirkelige frihedslovgivning, først og fremmest i loven om sognebåndsløsning. Her kan man med nogenlunde sikkerhed dokumentere, at Grundtvig var idéens hovedophavsmand eller i det mindste blandt dens fremmeste fortalere. Den var en logisk konsekvens af hans livs- og verdensanskuelse i det hele taget. Ideen blev taget op af folk, der bekendte sig som Grundtvigs tilhængere, og den blev gennemført som lov med støtte af Grundtvig selv. Endelig er det ikke svært at argumentere for, at denne lov har været af samfundsmæssig betydning.

3 Diskussionen om, hvor en tænker som f.eks. Grundtvig havde sine ideer fra, viser, at ideernes vandring gennem historien ikke foregår ad entydigt identificerbare, lineære stier. Mere herom senere.

4 De seks kriterier er inspireret af Freeden 2003, se f.eks. 65 f og 98 samt overvejelser om ideologi, politik og virkeliggørelse i Petersen og Petersen 2010, 23. 
Jeg skal i det følgende se på tre vigtige eksempler fra det danske samfundsliv, hvor Grundtvig enten i den almindelige bevidsthed eller i forskningen er fremhævet for sin betydning. Det gælder velfærdsstaten, højskolebevægelsen og demokratiet.

\section{Velfærdsstaten}

Bo Lidegaards bog om Danmark i det 20. århundrede er ganske åbenlyst udtryk for en socialdemokratisk-radikal tolkning af historien. Den handler om, hvordan velfærdsstaten og sikkerhedspolitikken blev udviklet i et parløb, der har sikret Danmark en enestående grad af velstand og fred. I de første kapitler skriver han om det århundrede, der gik forud, og kommer i den forbindelse blandt andet ind på Grundtvigs rolle:

Grundtvigs særlige sociale vision [har] præget udviklingen af Danmarks udgave af den europæiske velfærdsstat, hvor den sociale sammenhængskraft har været en afgørende bestræbelse. Hans berømte linjer,

Og da har i rigdom vi drevet det vidt,

Når få har for meget og færre for lidt,

har på godt og ondt stået som et credo over den danske velfærdspolitik i mere end hundrede år. Her ligger den åndelige rod til bestræbelsen på ikke at tilsidesætte hensynet til den, der har mindre, når der skal skabes muligheder for den, hvem mere er givet (Lidegaard 2011, 34).

Lidegaard er en ferm sprogbruger. Han skriver faktisk ikke, at Grundtvig skabte velfærdsstaten, men den ubefæstede læser af Lidegaards gennemgang kunne meget let komme til at tro det (Møller 2013).

Kim Arne Petersen har vist, hvordan denne transformation af Grundtvig til socialdemokratisk velfærdsstatspolitiker er foregået ikke mindst i 1930erne (Pedersen 2002 og 2013; Møller 2005). Esben Lunde Larsen giver mere nutidige eksempler (Larsen 2012, 44, 53). I forskningslitteraturen er der ingen, der hævder, at Grundtvig kan tages til indtægt for en velfærdsstatslig fordelingspolitik. Men man kan også spore en vis uvilje mod at indrømme, at det forholder sig sådan, eller som hos Viggo Morten- 
sen ligefrem en eksplicit vilje til at se bort fra Grundtvigs minimalistiske socialpolitik:

Grundtvig taler naturligvis ikke om socialetik eller overhovedet om "det sociale", for han talte ikke latin, men dansk. Alligevel var sagen der hos den gamle selv, og den er i hvert fald uomgængelig, skal man i dag hævde det grundtvigske på tidens betingelser (Mortensen 1985, 86).

Det kan dokumenteres temmelig entydigt, at Grundtvig var imod udsigten til en på demokratisk grund baseret beskatning med henblik på redistribution af midlerne til fattige. I et af sine Mands Minde-foredrag fremlagde han som et skræmmebillede for sine tilhørere den mulighed, at staden København fik lovgivning vedtaget af almindeligt stemmeflertal, således at de rigeste skulle beskattes, og at provenuet heraf skulle fordeles mellem alle andre. Det ville ifølge Grundtvig føre til byens ødelæggelse, fordi det ville give "Handel og Vandel og al udbredt Virksomhed et Knæk" og "befordre baade Fattigdom og Dovenskab, Ødselhed og Nærighed, Svir og Spil og slette Sæder” (Grundtvig 1838, 39).

Grundtvig udlagde sine egne linjer om, at få har for meget og færre for lidt, som et udtryk for det modsatte af, hvad det siden blev forstået som, nemlig i forbindelse med et ønske om fuld næringsfrihed og afskaffelse af al anden forsørgelsesret end den mellem forældre og børn:

i Danmark, hvor Selveiernes Antal er godt i Tiltagende, og hvor de store Fabriker Gud skee Lov! er faa, vil det ikke falde vanskeligt at redde Selvhaves Liv, afskaffe al anden Forsørgelses-Ret end den indbyrdes mellem Forældre og Børn, og at indføre saa stor en Nærings-Frihed, at det kan gaae, som der staaer i Visen: Faa har for meget og Færre for lidt (Grundtvig 1848a, 239).

Han var endvidere imod en lov om tjenestemandspension, en modstand der forargede en del i hans samtid (Møller 1950, 85; Thaning 1949, 68). Det i denne sammenhæng oftest fremhævede eksempel er hans holdning til den såkaldte forsørgelsesparagraf $\mathrm{i}$ grundloven. Han var som medlem af den grundlovgivende rigsforsamling imod forslaget om retten til statslig forsørgelse som "en af de største Ulykker, som kunde ske" (Petersen og Petersen 2010, 70ff; Pedersen 1999, 48). Hans alternative forslag lød: "Der 
skal, saavidt muligt, sørges for, at fattige Gamle, Syge og forladte Børn kunne finde offentlige Tilflugtssteder, og selv de fattigske kunne have Adgang til folkelig Oplysning og Dannelse" (Beretning 1849, 3208). Dette forslag indebar en fortsættelse af de gældende patriarkalsk-filantropiske principper for fattighjælp, som Grundtvig selv havde stiftet bekendtskab med, da han som kapellan i Udby var bestyrer af sognets fattigkasse (Begtrup 1899). Forslaget er lejlighedsvis gengivet i litteraturen med et komma for meget mellem "fattige" og "Gamle" (Andersen 1940, 39; SkovgaardPetersen 1985, 274; Wåhlin 1999, 283), altså som en slags opblødning af Grundtvigs ret strenge kriterier for modtagelse af offentlig hjælp, idet det ville indebære, at både gamle og fattige ville have ret til forsørgelse, men denne tolkning er der altså ikke hjemmel for i det stenografiske referat af forhandlingerne på den grundlovgivende rigsforsamling (Møller og Ravn 2014). ${ }^{5}$

Som argument mod retten til offentlig forsørgelse af fattige sammenlignede Grundtvig med forholdene i England, hvor indførelsen af denne ret havde betydet så stor en vækst i udgifterne, at opgaven havde været vanskelig at løfte, selv for så rigt et land. Hvis man i Danmark indførte en tilsvarende forsørgelsesret, ville man forpligte "den danske Regjering til at føde hele det danske Folk uden at have et England at beskatte" (Beretning 1849, 2608). ${ }^{6}$

Spørgsmålet er, om man deraf kan slutte, at Grundtvig som socialpolitiker var minimalstatsliberalist? Hans synspunkter ligner unægtelig mere vore dages økonomiske liberalister end vore dages socialdemokratiske fordelingspolitik. Der er altså belæg for at kalde ham "liberal om en hals"? Men man skal hæfte sig ved, at økonomi som politisk eller videnskabelig

\footnotetext{
5 Se dog et eksempel med komma i Danskeren 1848, 237.

6 Se også: Pedersen 1999, 49; Sml. Grundtvig 1836, 44.

7 Wåhlin 1989, 285. Nogle sider længere fremme trækker W. dog vældigt i land: "Om man vil kalde Grundtvigs økonomi-forståelse for småborgerlig, reaktionær, liberal, konservativ, evolutionær, fysiokratisk - eller hvad, vil jeg overlade til andre at skændes om. Derimod vil jeg kalde den realistisk og dansk.” (288). Hermed lægger Wåhlin sig tæt op ad Thanings vurdering af Grundtvig som politiker. Lars Kaae fremhæver vha. en marxistisk forståelsesmatrix Grundtvigs skepsis over for store industrivirksomheder ("kapitalismen") og ser Grundtvigs modstand mod forsørgelsesparagraffen som et udtryk for en "opposition mod den legitimering af en produktionsmåde, som en grundlovsfæstet fattighjælpsparagraf ville udgøre" (Kaae 1986, 114).
} 
disciplin næppe har ligget Grundtvig meget på sinde: “Oeconomien er Noget af det, jeg mindst forstaaer mig paa” (Grundtvig 1831, 32). Det giver lige så meget mening at kalde Grundtvig konservativ på dette punkt, fordi han i virkeligheden ikke ønskede sig ændringer fra det bestående (jf. Huntington 1957).

\section{Højskolebevægelsen}

Grundtvig ytrede sig fra begyndelsen af 1830erne jævnligt om behovet for en uddannelsesreform. Han betragtede den lærde skole, der lagde vægt på fagene græsk og latin, som ødelæggende for ungdommen, og han blev en markant skikkelse i uddannelsesdebatten. Der er dog flere forhold, der taler for, at der ikke er nogen lige vej fra Grundtvig til grundlæggelsen af de første folkehøjskoler.

For det første var ikke alle Grundtvigs markante synspunkter originale. ${ }^{8}$ Når det handler om almuen, der ved uddannelse skulle forædles til et højere dannelsesniveau, delte han synspunkt med de fleste reformpædagoger i Europa fra det 18. til det 20. århundrede, og i spørgsmålet om folkets, hhv. nationens betydning, var han en del af en tilsvarende bred europæisk politisk bevægelse, der tillagde folket afgørende vægt politisk og kulturelt. Det 19. århundrede var nationalismens århundrede: At modersmålet og historien, det historisk-poetiske for at tale grundtvigsk, skulle udgøre en større del af pensum i skolerne, var en naturlig konsekvens af både den politiske og kulturelle/litterære nationalisme (Gellner 1983).

Dertil kom, at Grundtvig sjældent gav sine tanker en konkretiseringsgrad, der gjorde dem operationaliserbare eller handlingsanvisende. Det nærmeste var planerne om omlægningen af undervisningen på Sorø Akademi, der trods Christian VIII's velvilje aldrig blev virkeliggjort.' Det var med fuldt overlæg fra Grundtvigs hånd, at han måtte "giøre det kort og

8 Kritikken af latinskolen var udbredt, så presset i retning af en højere skole, der lagde vægt på realfagene, var stort. Grundtvig var dog slet ikke tilhænger af realfag, altså moderne fremmedsprog, merkantile fag eller naturfag. Heller ikke udtrykket "den sorte skole" kan tillægges Grundtvig. Det forekom allerede i 1790erne (Olsen 1794, 21).

9 F.eks. med anvisninger på et par gode bøger at læse (Grundtvig 1840b, 23, 27), jf. (Grundtvig 1843b). 
holde det svævende" (Grundtvig 1840b, 17), når det handlede om skoleplaner. ${ }^{10}$ I 1854 afæskede den østjyske mæcen Peter Larsen Skræppenborg Grundtvig en specifikation af skoleplanen for Grundtvigs egen højskole som forudsætning for at donere penge til foretagendet. Grundtvigs svar var et tydeligt vidnesbyrd om, at han ikke begav sig af med praktiske anvisninger på, hvordan hans dannelsesfilosofi skulle omsættes i konkret skoledrift. Han henviste Skræppenborg til, hvad han tidligere havde skrevet om den sag, og kunne som det mest specifikke tilføje:

at det skal paa en skikkelig Maade være en Friskole for de Voxne, og at den skal stræbe baade at vække, nære og klare en høiere Betragtning baade af Menneskelivet i Almindelighed og af det danske Folks og Dannemandens Menneskeliv i Særdeleshed, end man sædvanlig møder (Grundtvig 1872, 241). ${ }^{11}$

Rødding Højskole (grundlagt 1844) blev opbygget som en konkurrent til en tilsvarende i Rendsborg grundlagt i 1842 og var en del af den nationale kamp i hertugdømmerne. Den danske ungdoms Bildungsrückstand i Slesvig havde vist sig at være en ulempe i den nationale modsætningskamp i den slesvigske stænderforsamling, så der måtte oprustes på dette felt. Det er ikke overraskende, at denne idé fik Grundtvigs opbakning, men på den anden side blev den også støttet fra så mange andre sider, at Grundtvigs støtte i realiteten ikke var afgørende.

En af hovedkræfterne i grundlæggelsen af Rødding Højskole, Chr. Flor, var tilhænger af Grundtvig (Lyby 1999, 70), men Grundtvig kvitterede ikke for interessen og ofrede hverken Flor eller hans skole nogen synderlig opmærksomhed ud over de begejstrede ord på Skamlingsbanken, og trods opfordringer dertil besøgte han aldrig skolen. Flor var dertil økonomisk afhængig af opbakning fra nationalliberale kredse i København, der støttede skolens nationale linje, men stod fjernt fra Grundtvig. Skolens pro-

${ }^{10}$ Han ønskede ikke at indlade sig “dybere i Udviklingen af den folkelige Høiskoles Indretning, [...] man skal, saavidt mueligt, lade Indretningen skabe og udvikle sig selv, hvad man uden al Fare kan, naar Bestyreren kun er en paalidelig Mand og har fri Haand." (Grundtvig 1840b, 16).

11 Grundtvigs egen påtegning til ansøgning om statsstøtte til skolen 1857 rummer dog en større grad af specificering. Pengene blev da også bevilget. (Skovmand 1960 II, 346). 
gram endte med kun i begrænset omfang at rumme elementer, der kan kaldes et specifikt resultat af grundtvigske skoletanker, eller som Thorkild C. Lyby forklarer det:

Virkeligheden er alle tings prøve, og Rødding-modellen havde vist sig bærekraftig. At Grundtvig havde haft så svært ved at se, at det var ad den vej, hans tanker om folkelig opdragelse skulle virkeliggøres, var ikke Røddings fejl (Lyby 1999, 87). ${ }^{12}$

Først i 1850erne kom der en fastere forbindelse mellem Rødding og Grundtvig, idet skolen begyndte at kalde sig selv grundtvigsk, og Grundtvig selv blev medlem af skolens tillidsmandskreds, dog stadig uden nogensinde selv at besøge skolen, og han anerkendte aldrig udtrykkeligt skolen som en frugt af sine tanker, om end man med Lyby kan argumentere for, at han gjorde det implicit (Lyby 1999, 87).

I 1851 søgte Kristen Kold foretræde for Grundtvig i København. Kold ville opnå støtte til den højskole, han ønskede at åbne tæt på Ryslinge på Fyn. Det begyndte med, at Kold blev introduceret af P.K. Algreen, en af Grundtvigs tilhængere. Kold berettede selv om episoden således:

Det er Kold fra Fyen, sagde Algreen. Aa, sagde Grundtvig, er det det! og vi ragede da strax uklar. Jeg vilde have mine Fyre i Skole, naar de var nylig konfirmerede, i en Alder af 14, 15, 16 Aar, men Grundtvig sagde: det duer ikke før de bliver 18 Aar. Jeg kan godt huske, at jeg sagde: Grundtvig kan ikke vide, hvorledes Bønderne er derhjemme, thi naar de er 18 Aar, har de allerede begyndt at lege Kjæreste, ryge Tobak, gjøre Pibe- og Uhrhandeler, og saa kan vi ikke faae dem beaandede. Jo, svarede Grundtvig, det kan vi nok. Nei, sagde jeg, som jeg har opfattet Forholdet, er min Mening den eneste rigtige. Jeg har altid været vis i min Sag, ogsaa naar jeg tog feil (Køster 1866, 70).

Det fremgår ganske tydeligt af Kolds egen redegørelse, at han og Grundtvig var uenige om skolens indhold og målgruppe. Og med hensyn til skolens form var der også i overført betydning et bredt farvand mellem Kolds

12 Jf. Grell 1998, Nissen 1994. 
lille husmandssted i Nørremarksgyden ved Ryslinge og det statelige akademi i Sorø. Grundtvig endte dog med at give Kold sin opbakning.

$\mathrm{Da}$ en gruppe af Grundtvigs danske og norske tilhængere samlede ind til en pengegave i 1853, var det med det formål "at grundlægge en "Folkelig Højskole” som skal ordnes efter Deres Bestemmelser og bære Deres Navn". Hvad giverne har tænkt om de på det tidspunkt allerede eksisterende højskoler, kan vi ikke vide, og det havde også ligget gavebrevsgenren fjernt at anlægge sammenlignende pædagogiske studier, men det er påfaldende, at giverne synes at mene, at der nu endelig var tilvejebragt midler til at påbegynde grundlæggelsen af en skole efter Grundtvigs eget hoved:

Vi vide det vel at en Pengesum, og især en saa liden, som den er endnu kunne bringe 7000 Rbd kun kan danne en ringe Begyndelse til en Bygning som den Skole for Livet der har staaet for Deres $\varnothing_{j e}$, men vi tage det som et godt Varsel for, at Kærligheden til Fædrelandet, en levende Folkeoplysning og begge disses utrættelige Forkæmper ikke maa være ringe, siden selv en saadan Begyndelse har kunnet gjøres i en betrængt Tid. Vi nære den Fortrøstning at den kan blive en god Begyndelse til et Værk, hvoraf De endnu i Deres Livs Aften maa kunne see glædelige Frugter, og at Samtid og Efterslægt vil bygge videre paa denne Grundvold til Guds Ære og det Fædernelands Bedste, De tjente i Kærlighed. ${ }^{13}$

Hvis der på dette tidspunkt allerede fandtes grundtvigske højskoler, er det ikke noget, der fremgår af teksten, og det er underforstået, at fænomenet endnu manglede at blive virkeliggjort. "Jeg under sandelig bønderne alt godt, og navnlig Oplysning," skrev C.J. Brandt i september 1853 til P.A. Fenger. De var begge underskrivere af gavebrevet. Derpå tilføjede han: "men nu bygger jo Alverden Bondehøjskoler, og vi 11 [underskrivere] satte ej Gr.s Navn og Fremtidssyn i Pant på, at det lod sig gøre, hvad enhver Amager kan gøre" (Skovmand 1960 II, 343).

Da Grundtvigs Højskole "Marielyst” endelig åbnede i 1856, kan man naturligvis ikke benægte, at der var tale om en højskole, der med rette var knyttet til Grundtvigs navn. Grundtvig viede den en om ikke intens, så dog regelmæssig interesse og opmærksomhed. (Skovmand 1960, II, 348).

13 Citatet er fra originalen på Grundtvigbiblioteket, Vartov. Se også Rosendal $1906,13$. 
Men i praksis var den bygget op efter Rødding-Ryslinge-modellen og ikke Grundtvigs oprindelige ønsker for omlægningen af undervisningen på Sorø Akademi..

Vender vi et øjeblik tilbage til Kolds beretning, er den både for sit indhold og sin ophavssituation kendetegnende for den konvergens af bondehøjskolereform og grundtvigianisme, der fandt sted efter 1850. Kold var antagelig, allerede inden han søgte foretræde for Grundtvig, klar over, at der var væsentlige forskelle mellem hans eget og Grundtvigs skolesyn. Ikke desto mindre søgte han og fik Grundtvigs opbakning til sin skole. Det er vidnesbyrd om, hvor central en skikkelse Grundtvig i praksis var blevet i Danmark ved århundredets midte, og derfor også et argument for den påstand, at han faktisk havde betydning. Kold endte i øvrigt også med at måtte give Grundtvig ret i, at det gik bedst med elever over 18 år. Videre skal man være opmærksom på den sammenhæng, Kolds beretning indgik i. Den blev holdt som tale ved Vennemødet på Store Ravnsborg på Nørrebro i 1866, hvor der ikke var lagt op til diskussion. Det var netop et vennemøde, hvis formål var "at styrke Samfunds-Baandet mellem os", og ikke et "Trættemøde" (Køster 1866, 3). Selv om Kold altså tydeligt tilkendegav sin uenighed med Grundtvig i sin beretning, var beretningsafgivelsen indfældet i en begivenhed, hvor den har udløst forsonende latter snarere end modstand og vrede. Kolds egne skoletanker var med andre ord på dette tidspunkt indfældet i grundtvigianismen uden nødvendigvis entydigt at være rundet deraf.

\section{Demokratiet}

I den almindelige danske erindringskultur henregnes Grundtvig til en af demokratiets frdre, og han er i overensstemmelse med denne tradition optaget på Undervisningsministeriets demokratikanon. ${ }^{14}$ Denne kanonisering bygger på en opfattelse, der ikke finder fuld opbakning i forskningen. For så vidt Grundtvig fremhæves som demokratisk pioner, sker det med begrundelse i hans frihedstanker (Larsen 2012, 193). Med hensyn til demokratiet som styreform var Grundtvig medlem af den grundlovgivende rigsforsamling og siden rigsdagsmand i flere omgange, hvilket om

${ }^{14}$ http://pub.uvm.dk/2008/demokratikanon/kap16.html, hentet feb. 2015. 
ikke andet må betragtes som en de facto-anerkendelse af repræsentative forsamlingers legitime andel i statens styrelse. I 1866 talte han imod den privilegerede valgret til Landstinget, men det er ikke belæg nok til at kalde Grundtvig demokratisk pioner. At drøfte, om Grundtvig var demokrat eller ej, er også et langt stykke af vejen en anakronisme. Den væsentlige politiske diskussion i 1840erne stod slet ikke om, hvor vidt der skulle indføres demokrati eller ej, alene af den grund, at demokrati ganske enkelt i det 19. århundrede var et skældsord. Af samme grund var der ingen af de ledende grundlovsfædre i 1848-49, der forestillede sig, at det var et demokrati, de var i færd med at indføre (Nevers 2011; se dog Nygård 2011). Når man relativt let kan fremdrage citater af Grundtvig, hvor demokratiet omtaltes nedsættende, hvad enten det er "pøbel-parisisk" eller "kræmmeramerikansk" (f.eks. Grundtvig 1831, 22), kan man altså ikke tage det som udtryk for, at han var ude af trit med sin tid (Birkelund 2008, 467).

Det er med andre ord ikke let i politisk forstand at indplacere Grundtvig. Han stod for klassiske liberale værdier som trykkefrihed og religiøs frihed, og han sad i en komité for ophævelse af negerslaveriet i Dansk Vestindien (Bugge 2003). Af de borgerlige rettigheder lagde han også vægt på, "at Eiendoms-Retten ikke blot er det Borgerlige Selskabs Grundlov, men ogsaa dets Grundvold, saa naar den tages bort, synker hele Bygningen i Grus" (Grundtvig 1848a, 236-237). Selv om det kan lyde som et principielt forsvar for al ejendomsret, skal udsagnet nok også forstås i sin politiske kontekst, især spørgsmålet om lensafløsning. Grundtvig forsvarede bondeselvejet, ikke lensbesiddernes ejendomsret (Kaae 1986, 120f).

Vigtigst af rettighederne var for Grundtvig skrive- og især trykkefriheden, som han vendte tilbage til gang på gang. ${ }^{15}$ Det var i overensstemmelse med de idealer, der herskede i hans ungdoms offentlige debat, og den sene enevældes selvforståelse. Den trykkefrihed, der var blevet indført af Struensee, blev aldrig formelt afskaffet, men den blev både de jure og de facto indskrænket uden at forsvinde helt (Munck 2014). Grundtvigs tilslutning til trykkefriheden udgjorde en integreret del af hans livsanskuelse, men kan forklares biografisk "hvis man vil have en simpel løsning"

15 Skrive- og trykkefrihed var ikke nødvendigvis synonyme. Grundtvig har antagelig skelnet således, at der med skrivefrihed mentes retten til at henvende sig til øvrigheden/kongen på skrift, og med trykkefrihed retten til at meddele sig til offentligheden. Se Grundtvig 1831, 70. Dertil kommer "Tale-Friheden" som selvstændig kategori (Kaae 1986, 103). 
(Michelsen 1979, 18-19). Han levede af og for at udgive sine ting, så det var ganske enkelt vigtigt for ham netop at kunne det.

Det nationale spørgsmål udgjorde en meget væsentlig del af Grundtvigs program, hvis det da ikke ligefrem udtømte det i 1848. Han ønskede "først og fremmest at banke Tyskerne, til de driver af, og derpaa med en ægte dansk Grundlov at faae Riget sat i Skik paany", som han sagde ved et vælgermøde. (Thaning 1949, 45, se også 52). Den opfattelse, at Danmark og det danske var en afgørende identitetsmarkør, deltes dog af de fleste af hans samtidige, ikke mindst de nationalliberale, der med Ejderpolitikken havde gjort det nationale princip til en afgørende del af deres program. Grundtvig var frem til 1848 helstatsmand, flirtede muligvis, mens den mulighed også stod åben for nogle nationalliberale, med tanken om en sindelagsgrænse (Fink 1950, 65). Både Thaning og Møller tager en passage i Grundtvigs tale i den slesvigske hjælpeforening 14. marts 1848 som udtryk for, at han gik ind for en deling (Thaning 1949, 61-2; Møller 1950, 63), men det er spørgsmålet, om den tolkning holder:

Kiendsgierninger er nemlig, som Engelskmanden meget rigtig siger, haardnakkede Krabater, og en saadan haardnakket Kiendsgierning er det, at Kongeriget Danmark, hvorvidt det saa end gik i gamle Dage, nu dog ikke gaaer et Fodsbred længere, end til Grændsen af Hertugdømmet Slesvig, og at det Danske Land gaaer i det allerhøieste kun saa vidt, som man taler Dansk, og igrunden ikke længer end man vil blive ved at tale Dansk, altså til ensteds, man veed ikke hvor, midt inde i Hertugdømmet Slesvig (Grundtvig 1848a, 89).

Grundtvig konstaterede, at den nationale grænse gik et andet sted end den statsretlige, men gik ikke så vidt som til at foreslå, at dette forhold skulle flytte den statsretlige grænse. Derimod gjorde han sig til talsmand for en ejderpolitik med ligestilling af dansk og tysk i Slesvig som forudsætning:

Spørgsmaalet er nu altsaa kun, hvad vi, efter at have indrømmet Kiendsgierningens Urokkelighed, kan giøre med Rette, og rimeligviis med Held, for at hævde vort gamle Krav paa hele Slesvig, og hævde Danskens 
utabelige Ret til i Hertugdømmet Slesvig i alle Maader at staae ved Siden ad Tydsken (Grundtvig 1848a, 90). ${ }^{16}$

Skulle der heri ligge et forslag om en slags deling af Slesvig, forlod han under alle omstændigheder synspunktet igen og udtrykte under Treårskrigen klart, at til "Hertugdømmet Sønder-Jylland har det Danske Folk Eiendoms-Ret, uden Hensyn paa, hvad Sindelag Indbyggerne har, og hvad Sprog, de taler, men til Hertugdømmet Holsten har det danske Folk slet ingen Ret" (Grundtvig 1849, 765). ${ }^{17}$ Han gik dog stærkt ind for, at alle folkegrupper i Slesvig skulle have eget skole og kirkesprog, dog under fortsat "dansk Høihed" (Grundtvig 1848a, 183, jf. 186).

Han ønskede som de nationalliberale at udskille Holsten, men ikke at inkorporere Slesvig i kongeriget (Grundtvig 1848a, 119f; Fink 1950, 64). Det er derfor også kun betinget, at man kan kalde hans synspunkt efter 1848 ejderdansk (jf. Lundgreen-Nielsen 1992, 108). Han mente ikke, at tyskerne i hertugdømmerne skulle pånødes dansk som sprog. Netop de tyske slesvigeres ret til eget sprog gjorde, at Slesvig ikke kunne indlemmes i kongeriget, for det ville gøre tysk til gyldigt sprog i Danmark, og tysk havde ifølge Grundtvig ingen steder hjemme, hverken på Rigsdagen eller i skolen: "For din Lunge, / For din Tunge / Tydsk er Edder og Forgift" (Grundtvig 1864, upag.). Først mod slutningen af sit liv synes Grundtvig at være gået mere klart ind for den statsretlige konsekvens af sine stærke nationale synspunkter: en deling af Slesvig (Grundtvig 1871, 93).

Ifølge den nu klassiske definition (Gellner 1983, 1) er nationalismen som politisk bevægelse kendetegnet ved ønsket om sammenfald mellem nationens og statens grænser. I henhold til denne definition kan man kun betinget kalde Grundtvig nationalist. Han betragtede ganske vist nationen som en helt afgørende identitetsskabende og -bærende faktor, og han anerkendte tidligere end de fleste, at Slesvig i dette spørgsmål var delt,

16 Tilsvarende synes en passage i Politiske Betragtning 1831, 60-61, om at lade slesvigerne selv afgøre deres tilhørsforhold ikke at indebære Slesvigs deling som et muligt udfald af denne afgørelse. Når disse passager ofte er blevet læst som et ønske om Slesvigs deling, kan årsagen være, at Grundtvig er blevet forstået inden for rammerne af den politiske nationalisme, der kendetegnede de nationalliberale, mens Lorenz Rerup antagelig har ret $\mathrm{i}$, at han skal forstås som litterær (eller kulturel) nationalist (Rerup 1992, 31).

17 Jf. Grundtvig 1850, 426, hvor en deling drøftes hypotetisk. 
men drog netop ikke den politiske eller statsretlige konsekvens. Hans interesse i landsdelen var i hvert fald ikke større, end at han kun besøgte Slesvig en eneste gang i sit voksenliv (Thyssen 1999, 49). Det samme må retfærdigvis siges om det for ham ligeledes magtpåliggende Norge.

Selv om Grundtvig lagde vægt på både det nationale og det liberale, regnedes han ikke til de nationalliberale, der - med Kaj Baagøs ord - ønskede "forandring fra enevoldsregimente til flertalsregimente. G[rundtvig]s mål var at indskrænke ethvert regimente” (Baagø 1955, 8). Her tillagde Baagø dog antagelig de nationalliberale for meget af en demokratisk ambition. Deres politiske kultur var væsentlig mere aristokratisk end demokratisk (Clemmensen 1999). Baagø mener, at de nationalliberale havde fåt deres impulser fra kontinentet, mens Grundtvig grundlæggende var påvirket af engelsk liberalisme, Locke og Smith. Grundtvig selv frabad sig at blive betegnet som konservativ eller liberal (Grundtvig 1848a, 171). Denne afvisning var antagelig også udtryk for en af tidens konventioner, der bød deltagere i det offentlige liv ikke at optræde som partigængere.

Baagø lægger vægt på, at Grundtvig opfattede enevælden som hvilende på en samfundspagt (Baagø 1955, 33). Denne tanke er overtaget af Tine Damsholt (Damsholt 1995), der i tilgift inddrager Jens Arup Seips undersøgelse fra 1957 af “Teorien om det opinionsstyrte enevelden” (Seip 1958). Seip undersøgte, hvad baggrunden var for den politiske kultur, der opstod i Norge omkring 1814, og identificerede, hvad vi i dag beskriver som en borgerlig offentlighed i det 18. århundredes sidste årtier i Danmark-Norge. Denne offentlighed opererede ifølge Seip med en teori om, at den enevældige monark styrede i overensstemmelse med den offentlige mening, som udgjorde folkesuverænitetens stemme. Man havde på dette tidspunkt helt opgivet forestillingen om kongemagtens guddommelige legitimitet. I stedet var man af den opfattelse, at kongens enevældige magt var blevet ham overdraget af folket i 1660, og således forenedes absolutismen med en nyere tids naturretstænkning.

Det er denne opfattelse, som Grundtvig ifølge Damsholt overtog, og Damsholt gør denne opfattelse til den blivende demokratiske kerne i Grundtvigs politiske teori:

Det centrale demokratiske element var for Grundtvig ikke formen, forfatningen eller spørgsmålet om direkte demokrati eller repræsentativt demokrati. [...] Det centrale er for Grundtvig, at folkeviljen, eller for at 
bruge Grundtvigs eget ord 'folkestemmen', kan komme frit til udtryk, og at de magthavende frivilligt følger denne folkestemme. [...] Dette er kernen i Grundtvigs folkestyreopfattelse, som er konsistent, og som han følger hele sit liv (Damsholt 1995, 147).

Damsholts idé om Grundtvig som proto-demokratisk tilhænger af en kontraktteoretisk opfattelse af enevælden har vundet tilslutning (Birkelund 2008, 468; Nygaard 2014). Kim Arne Pedersen har udbygget Damsholts tanke. Det er Pedersens opfattelse, at Grundtvigs frihedssyn står på menneskerettighedernes grund, og at Grundtvig som kontraktteoretiker står i gæld til især Locke. Pedersen bemærker, at denne tolkning modsiges af Mands Minde-foredragene, men tillægger dem mindre vægt (Pedersen 2004, 22). Som hos Baagø - og Wåhlin - bygger antagelsen om påvirkningen fra Locke især på diskutable analogislutninger. Grundtvig var karrig med selv at henvise til, hvor han havde sine ideer fra, og var så egensindig i sit ordvalg, at det antageligt er vanskeligt at eftervise hans inspirationskilder ved verbalsammenfald. Hvorom alting er, kan det fastholdes, at Grundtvig var tilhænger af enevælden helt frem til Grundlovens givelse (Andersen 1940; Lundgreen-Nielsen 1999). Som han selv skrev i 1850:

jeg bekiender frit, at nu som før vilde jeg ønske Danmark en Konge med Enevoldsmagt og et frit Folkeraad, som hverken var lovgivende eller lovskrivende eller var saa langtrukkent og dyrekiøbt som det nærværende (Grundtvig 1850, 281).

Uanset hvordan man vender og drejer denne formulering, kan den ikke tolkes som udtryk for en opbakning til en liberal kontraktteori. Man skal være opmærksom på, at Grundtvig i forlængelse af denne formulering anerkendte eksistensen af "en lovgivende Rigsdag" og et juridisk ansvarligt ministerium som en af øjeblikket dikteret nødvendighed (Grundtvig 1850, 281). Grundtvig var ikke uden pragmatisk sans, men han betragtede alligevel grundlæggende kongen som statens konstitutionelle centrum. Forudsætningen for at tale om en kontraktteori i liberal forstand skulle være, at Grundtvig for det første havde udviklet en klar forestilling om folkesuverænitet, altså at der var en form for jævnbyrdighed mellem konge 
og folk, og for det andet var af den opfattelse, at kontrakten mellem konge og folk var opsigelig - at den rummede en oprørsparagraf.

I betragtning af, hvor stor en vægt Grundtvig lagde på folket i det hele taget, var han påfaldende lidt optaget af folkesuveræniteten. Han omtalte "Folkets Selv-Besiddelse" (Grundtvig 1848a, 218). Ved en anden lejlighed skrev han om folkets ejendomsret til Slesvig (Grundtvig 1849, 765), men $\mathrm{i}$ ingen af tilfældene kan det tages som et udtryk for en systematisk hævdelse af folkesuveræniteten som forfatningsmæssigt princip.

Når han talte om suverænitet, synes han snarere at have tilsluttet sig det monarkiske princip, som det kaldtes. ${ }^{18}$ Det princip var bygget på den opfattelse, at suverænitet ikke kunne deles. Man kunne i en forfatning opbygget efter det monarkiske princip godt have en funktionsdeling af magten. I den sene danske enevælde f.eks. var domsmagten udskilt som selvstændig (Grundtvig 1831, 63), men grundlæggende ville en deling af suveræniteten føre til suverænitetens undergravelse, lyder argumentet for det monarkiske princip. Spørgsmålet er altså, om Grundtvig betragtede monark og folk som jæunbyrdige kontrahenter, om han så på "den levende Forbindelse mellem den uindskrænkede Konge og det fribaarne Folk" (Grundtvig 1836, 60) som et kontraktligt forhold med en opsigelsesklausul?

Digtet, der indledes med linjerne "Konge-Haand og Folke-Stemme, I Begge stærke, begge fri” (Grundtvig 1839, genoptrykt i Grundtvig 1843), er programmatisk for Grundtvigs forestilling om magtdelingen mellem folket og kongen i tiden efter stænderforsamlingernes indførelse. Han citerede det selv som medlem af den grundlovgivende rigsforsamling (Beretning 1849, 2874), og de to grundbegreber findes også i Det danske Fiir-Kløver fra 1836: “Kongens Eneherredømme' og 'Folkets aabenlydte Stemmefrihed' er Rigets Arilds-Lov” (Grundtvig 1836, 13). Man skal i den forbindelse erindre, at stemme ikke betyder stemmeafgivelse, men ytring. Det er blevet hævdet, at Grundtvig opfattede den enevældige monark som repræsentant for folket (Kaae 1986, 90), men det er antagelig ikke repræsentation, der ifølge Grundtvig kendetegner forholdet mellem konge og folk. Kongen er en uden for folket suveræn instans, der til gen-

${ }_{18}$ Begrebet blev introduceret af Schlegel i det 19. århundredes første årti (Holmøyvik 2013, 312). Begrebet fik sin teoretiske udformning af Benjamin Constant og ikke mindst Friederich Julius Stahl (Stahl 1845), se Prutsch 2012, 190, og Kirsch 1999. 
gæld har som forpligtelse at sikre folkets frihed, først og fremmest til at ytre sig. ${ }^{19}$

I en samtidig optegnelse, som Grundtvig kaldte "Politisk Troes-Bekiendelse og Tanke-Gang” (Pedersen 2004, 29), lyder dens første artikel helt i overensstemmelse med den poetiske udgave:

at $\mathrm{i}$ et velindrettet borgerlig Selskab maae Én have Ret til at byde og alle Undersaatterne være pligtige at lyde. Min anden Troes-Artikel er derimod den, at ligesaavel som Øvrigheden har fri Haand, maa Undersaatterne have fri Mund, have deres Frisprog (Fasc. 189.I; cit. efter Pedersen 2004, 30).

Først i den tredje artikel udtrykker Grundtvig ønsket om, at dette styre måtte være retfærdigt og ikke undertrykke borgernes rettigheder. Det kan ikke undre, at Grundtvig foretrak en retfærdig frem for en uretfærdig konge, men måtte folket i givet fald gøre oprør mod den uretfærdige? Svaret på dette spørgsmål er afgørende for vurderingen af, hvilken slags kontraktteori Grundtvig abonnerede på.

Hele det første kapitel af Politiske Betragtninger fra 1831 er et katalog af historiske eksempler på, hvor skidt det kan gå, når folket gør oprør mod deres retmæssige konge, og "Statsroret aabenbar er i Pøbelens og Børnenes Hænder” (Grundtvig 1831, 12). Anledningen til skriftet var Julirevolutionen, som Grundtvig tog stærkt afstand fra. Selv under den forudsætning, at "Chartet var brudt", altså at kongen havde overtrådt forfatningen af 1814, "saa er det dog klart, at blot for Chartets Integritet vilde besindige Folk ikke sætte hele Landets Lykke paa Spil, thi blot for et Stykke Papir kommer det sig kun Bog-Orme at giøre Oprør og [...] lade Gaderne strømme med Blod" (Grundtvig 1831, 15).

Grundtvig betragtede statsomvæltningen 1660 som et stort fremskridt (“Kæmpeskridtet”), hvorved "Danmark øiensynlig tilbagevandt Hælvten af sin gamle, naturlige Forfatning, og i Grunden, som Tiden har viist, den hele". Folket gav kongen "Ene-Herredømmet", og kongen gav folket "Stemme-Friheden" ved denne lejlighed, men disse gaver kunne ifølge

${ }^{19}$ Denne pointe findes også hos Lars Kaae (Kaae 1986, 96), der antagelig ser fuldstændig ret, når han siger, at Grundtvig opfattede staten som garanten for friheden - med det stærke forbehold, at "staten" var Grundtvig en uting (Grundtvig 1831, 36; Danskeren nr. 24, 1848, 375-378). Suveræniteten tilhørte kongen. 
Grundtvig ikke tages tilbage, for "hvem der tager sine Gaver igien, hans Børn bliver sorte" (Grundtvig 1836, 23). Statsskibets ror skulle forblive i "Styrmandens Haand" (Grundtvig 1831, 9). Man kan altså godt i Grundtvigs udlægning tale om enevældens indførelse som en samfundspagt, men denne pagt var for ham uigenkaldelig, uden oprørsparagraf. Det var et afgørende punkt for Locke, at samfundspagten var opsigelig, at den havde en såkaldt oprørsparagraf. Det vil sige, at hvis man vil pege på en moderne naturretsfilosof og kontraktteoriker som inspiration for Grundtvig, taler omstændighederne for Hobbes snarere end for Locke, for arvekongedømme snarere end for valgkongedømme, og dermed for en i forfatningsretlig forstand mere konservativ end liberal tradition. ${ }^{20}$

Grundtvigs opfattelse af monarkiet havde muligvis også andre kilder end den kontraktretlige teori, nemlig den klassiske græsk-romerske statsteori, der opererede med tre forskellige forfatningstyper, den demokratiske, den aristokratiske og den monarkiske (Møller 2014). Hver af disse rene styreformer havde positive egenskaber, men hvis de stod alene, risikerede de at udarte sig til tyranni, oligarki eller anarki, og derfor blev den såkaldt blandede forfatning et ideal, fordi i den stat, der i sig rummede balancen mellem demokratiske, aristokratiske og monarkiske elementer, ville der herske stabilitet, harmoni og retfærdighed. Gennem historikeren Polybios fik denne teori om den blandede forfatning et langt efterliv, og den var naturligvis kendt - om end langt fra delt - af enhver klassisk dannet politisk tænker i det 18. og 19. århundrede (Hansen 2012, 28). Hos Grundtvig ser man tydelige spor af denne tankegang under forfatningsrøret i 1848:

ved "Stats-Forfatning" tænker man slet ikke paa Folks Forfatning, men paa en vis almindelig Styre-Maade, der lader sig "forfatte" og prænte omtrent ligesom en Bog, enten monarkisk, aristokratisk eller demokratisk. Vist nok tænker man sædvanlig, at Folkets Forfatning eller Tilstand retter sig efter Stats-Forfatningen, men al Erfaring lærer det modsatte, da Folk under enhver tænkelig Styre-Maade, Regjeringsform

${ }^{20}$ Grundtvig ejede et eksemplar af Lockes erkendelsesteoretiske hovedværk $A n$ Essay Concerning Human Understanding, Hobbes, statsteoretiske hovedværk Leviathan og Adam Smiths Wealth of Nations ved sin død, men ikke Lockes Two Treatises on Government. Fortegnelse 1873, Kat.nr. 8065, 8088, 8250, 8251. Både Hobbes og Locke nævnes i Verdens Krønike 1812 (US II, 290f.). 
eller Stats-Forfatning, har fundet sig snart lykkelige og snart ulykkelige (Grundtvig 1848a, 376). ${ }^{21}$

Grundtvigs løsning på problemet var ikke som hos klassikerne at indføre en blandet forfatning, men at holde fast i det velkendte, monarkiet, suppleret af et svagt demokratisk element. Aristokratiet havde som magtbærende stand allerede i slutningen af det 18. århundrede mistet sin legitimitet, og mod det rene demokrati som styreform kunne Grundtvig opremse mange historiske eksempler på, hvor galt det ville gå. Monarkiet var Grundtvigs valg, fordi alternativerne $i$ hans univers var uacceptable.

Skal man føre denne tanke videre, har Kim Arne Pedersen lagt en interessant grundsten med sine studier af Grundtvigs forhold til det jødiske folk (Pedersen 2014). I forlængelse heraf ligger det på den åbne hånd at studere Grundtvigs forhold til den gammeltestamentlige kongemagt. Skal man tale om Grundtvig som samfundspagtstænker, undgår man næppe heller at inddrage den gammeltestamentlige, asymmetriske pagtstænkning, idet der hos Grundtvig ikke sjældent drages paralleller mellem tre hierarkiske relationer: folkets forhold til dets øvrighed, børns til deres forældre og menneskers til Gud:

Saaledes staaer da Faderligheden hos vore Enevolds-Konger i allernøieste Forbindelse med Barnligheden hos deres Undersaatter, og naar Man alligevel, som jeg slet Intet har imod, helst giver 'Gud Æren', da skulde Man dog ikke her anvende Ord-Sproget: vor Herre er Daarers Formynder, men heller Skrift-Sproget: Børnenes Engle see altid den himmelske Faders Ansigt! (Grundtvig 1836, 25) ${ }^{22}$

Som altid lagde Grundtvig vægt på kærligheden og ikke magten som den ideale relation mellem øvrighed og undergivne, men det var ham ikke om at skjule, at der var tale om et grundlæggende over- og underordningsforhold, som ikke kunne ændres. Mellem børn og forældre, mellem folk og konge og mellem kristne og Vorherre bestod det samme klare hierarki, uden hvilket der ikke kunne bestå nogen orden (jf. Grundtvig 1831, 23).

${ }^{21}$ Jf. Grundtvig 1817, XXVIII-XXX; Grundtvig 1831, 17-18.

22 Jf. Matt 18,10; se også Grundtvig 1848b. 


\section{Afslutning}

Om Grundtvigs betydning for velfærdsstaten, højskolen og forfatningen kan man sige, at han ganske vist havde synspunkter om både fattigforsørgelse, undervisning og konstitution, men at han hverken var økonom, pædagog eller politiker. I spørgsmålet om velfærdsstaten og demokratiet kan man aflive forestillingen om Grundtvigs betydning eller virkning alene på det første af de seks kriterier, nemlig at Grundtvig skal have haft ideen, for at den kan tillægges ham. Han havde ganske enkelt ingen udviklede forestillinger om hverken velfærdsstat eller demokrati, og for så vidt han havde, var han imod. I spørgsmålet om højskolen opfyldes flere af kriterierne, men ikke fuldstændigt, idet der ikke var tale om en tradering af Grundtvigs oprindelige ideer til Rødding eller Kolds skole i Ryslinge, og at det trak ud med Grundtvigs tilslutning til den tanke, at skolen var en frugt af hans tanker. Rødding Højskole og dermed højskolebevægelsen blev i hvert fald ikke skabt af Grundtvig selv, og selv om en af hovedaktørerne var inspireret af Grundtvig, blev skolen kun nølende og i krebsegang en del af den grundtvigske bevægelse. Først i 1860erne kom der via nogle af Grundtvigs yngre disciple, ikke mindst i "Lille Theologicum", en klarere forbindelse mellem Grundtvig og flere af de nye folkehøjskoler.

Grundtvigs ideer havde ofte så generel eller almindelig en karakter, at de sjældent var direkte handlingsanvisende. Hans danskhedsprogram på Den grundlovgivende Rigsforsamling fejrede dog en enkelt meget klar og ofte overset triumf, idet hans forslag om at udskifte et fremmedord (Emanation) med et dansk (Udstedelse) vandt en for rigsforsamlingen enestående tilslutning med 142 stemmer mod 1 (Forhandlinger 1849, 970-971 og 985). I Grundtvigs egen motivering for forslaget spillede han selvironisk på det forhold, at også han havde ret til at vinde en afstemning for én gangs skyld. Det er altså ikke rigtigt, når det så ofte anføres, at Grundtvigs eneste indflydelse på Junigrundloven var i $₫ 79$ at indføre løftet om mundtlighed og offentlighed i retsplejen, hvilket i øvrigt heller ikke er nogen ringe bedrift. Men på den anden side adskilte den relativt ringe indflydelse ikke Grundtvig fra så mange andre medlemmer af Den grundlovgivende Rigsforsamling. Indflydelse havde i realiteten kun medlemmerne af de udvalg, der bearbejdede udkastet. Alle andre fik som regel deres ændringsforslag forkastet (Thaning 1849, 65). 
Hvis man beskriver Grundtvig som ensom og isoleret, skal det altså tages med det forbehold, at det gjorde ham til medlem af en stor gruppering på Den grundlovgivende Rigsdag, nemlig de ensommes og isoleredes parti. Helt alene med sine synspunkter stod han nu heller ikke. Grundtvigs alternative forslag til forsørgelsesparagraffen fik ved afstemningen 82 stemmer imod sig, men altså trods alt 22 stemmer for (Petersen 1999, 46). Men for at kunne give en mere retvisende vurdering af Grundtvigs rolle på Rigsdagen må man huske, at disciplinen politik stadig var ganske ny for de fleste, og at især den ældre generation til de yngres irritation i fuld alvor troede, at det kunne lade sig gøre at fremme sine synspunkter uden taktiske overlæg ved argumenter alene. Som et rigsdagsmedlem noterede i sin dagbog: "Det er ubegribeligt, at Ørsted og Grundtvig kunne faae i Sinde at holde Time lange Taler i Rigsforsamlingen om Ting, der er Bagateller i Sammenligning med de Forhold, hvorunder vi leve" (Bjørn og Larsen 1999, 90).

Det var en erkendelse, som Grundtvig selv i hvert fald i teorien var nået til, nemlig at det går "de saakaldte uafhængige Medlemmer, som intet Parti har i Ryggen, at de kan rigtignok frit sige hvad de vil, men Ingen hører det" (Grundtvig 1848a, 86). Senere som rigsdagsmand kom Grundtvig i fastere allianceforhold med egentlige politikere, og så udeblev resultaterne heller ikke. Det faldt sammen med fremvæksten af den grundtvigske bevægelse som et bredere samfundsfænomen.

Med sit sprog og personlige karisma pådrog han sig sent i livet stadig fleres beundring, og det blev hans "skæbne at blive overskygget af den [...] bevægelse, der med større eller mindre ret kaldes ved hans navn" (Lindhardt 1964, 7). Grundtvig var imidlertid stadig centrum. Frem til og med begravelsen i 1872 var det den konkrete, biografiske Grundtvig, der udgjorde vennemødernes naturlige midte. Uanset den afstand, som deltagerne havde til Grundtvigs egne synspunkter, orienterede de sig mod ham som et gravitationspunkt.

Denne proces fortsatte efter hans død. Grundtvig blev en mærkat, et brand eller et ikon for en samfundsudvikling, for hvilken han naturligvis ikke kunne have noget personligt ansvar. Det egentligt grundtvigske indhold i meget af det, der har kaldt sig grundtvigsk gennem tiderne, har udviklet sig til en næsten homøopatisk grad af fortynding, men stadig med den biografiske N.F.S. Grundtvig som et ofte meget eksplicit - om end ikke sjældent fjernt - centrum. Det fænomen er af mange grunde i sig selv interessant at studere, men det er også grund til, at studiet af hans 


\section{Jes Fabricius Møller}

person, altså den biografiske Grundtvig, hans liv og virke, aldrig har tabt relevans: "Grundtvig er en af de skikkelser, der fordømmer eftertiden til det slid at forstaa og fortolke sig” (Høirup 1951, 167).

\section{Litteratur}

Verker af Grundtvig

- (1812), Kort Begreb af Verdens Krønike, København, Andreas Seidelin.

- (1817), Udsigt over Verdens-Krøniken fornemmelig i det Lutherske Tidsrum, Kjøbenhavn, Andreas Seidelin.

- (1831), Politiske Betragtninger med Blik paa Danmark og Holsteen, København, Wahlske Boghandel.

- (1836), Det danske Fiir-Kløver, Kjøbenhavn, Wahlske Boghandel.

- (1838), Mands Minde foredrag nr. VIII 6. juli 1838, udgivet i A.M. Møller, Grundtvigs Mands Minde, samt egne erindringer og tidsbilleder, Forlaget Falcon 2013, 38-39.

- (1839), 28de Mai i Det danske Samfund, Kjøbenhavn, u.f.

- (1840), Fasc. 189.I (o. 1840), udg. af Kim Arne Pedersen i Grundtvig-Studier 2004.

- (1840b), Bøn og Begreb om en Dansk Høiskole i Soer, Kjøbenhavn, Wahlske Boghandling.

- (1843), Sange til Festen den 28de Mai, Kjøbenhavn, J.D. Qvist.

- (1843b), Om Indretning af Sorø Academi til en folkelig Højskole, trykt i Danskeren Bd. 1, 1889, 276-284.

- (1848a), Danskeren, København, Gibe/Louis Klein.

- (1848b), Bededags-Tale for Rigsdagen i Danmark, København, Louis Klein.

- (1849), Danskeren, København, J.D. Qvist.

- (1850), Danskeren, København, J.D. Qvist.

- (1864), Kong Frederik den Syvendes Ihukommelse, København, Karl Schønbergs Forlag.

- (1871), Tale i J. Kristian Madsen (Udg.), Det kirkelige Vennemøde i Kjøbenhavn i Pintseugen 1871, København, K. Schønbergs Boghandel, 92-94.

- (1872), Smaaskrifter om den historiske Høiskole, København, 1872. 


\section{GRUNDTVIGS BETYDNING FOR SAMFUNDET}

\section{Litteratur}

Andersen, Poul (1940), Grundtvig som Rigsdagsmand, København, Gyldendal.

Balle, Thorstein (2014), "Myten om Grundtvigs indflydelse på folkeskolen” i Grundtvig-Studier 2014, 65-98.

Begtrup, Holger (1899), "Af en gammel Fattigprotokol”, Højskolebladet nr. 50

Beretning om Forhandlinger paa Rigsdagen 1848-1849.

Birkelund, Regner (2008), Frihed til falles bedste, Aarhus, Aarhus Universitetsforlag.

Bjørn, Claus og Larsen, Christian (udg.) (1999), Men meest talte vi om Landboeforholdene... Thorkild Christian Dahls dagbog fra Den grundlovgivende Rigsforsamling 1848-49, København, Landbohistorisk Selskab 1999.

Bugge, K.E. (2003), Grundtvig og slavesagen, Aarhus, Aarhus Universitetsforlag.

Baagø, Kaj (1955), “Grundtvig og den engelske liberalisme” i Grundtvig-Studier 1955, 7-37.

Clemmensen, Niels (1999), "Fra junigrundlov til revideret junigrundlov 18491866" i Den jyske historiker nr. 83-84, 181-203.

Damsholt, Tine (1995), “'Jeg er en gammel Royalist, det ved De nok' - Elementer i Grundtvigs politiske tænkning” i Grundtvig-Studier 1995, 140-162.

Fink, Troels (1950), "Grundtvig og Sønderjylland” i Historie/Jyske Samlinger Ny række, bd. 1, 59-71.

Fortegnelse over den af N.F.S. Grundtvig efterladte Bogsamling, som bortsalges ved offentlig Auction i Klædeboderne Nr. 38, Mandagen d. 29 September 1873, København.

Fransson, Ola (2003), "I skuggan av Grundtvig" i Sanders og Vind (red.), Grundtvig - nyckeln till det danska, Göteborg, Makadam, 126-149.

Freeden, Michael (2003), Ideology - A very Short Introduction, Oxford, Oxford University Press.

Gellner, Ernest (1983), Nations and Nationalism, Ithaca, Cornell University Press.

Grell, Helge (1998), Vision og virkeliggørelse, Aarhus, Aarhus Universitetsforlag.

Hansen, Mogens Herman (2012), Demokratiets historie fra oldtid til nutid, København, Museum Tusculanum.

Holmøyvik, E. (2013), “Frå revolusjon til restaurasjon”, i (samme red.) Tolkningar av Grunnlova, Oslo, Pax, 307-337.

Huntington, Samuel P. (1957), "Conservatism as an Ideology" i The American Political Science Review, Vol. 51, No. 2. (Jun., 1957), 454-473. 


\section{Jes Fabricius Møller}

Høirup, Henning (1951), "Midler og maal i Grundtvig-forskningen” i Dansk Teologisk Tidsskrift, 14/3, 167-188.

Kirsch, Martin (1999), Monarch und Parlament im 19. Jahrhundert, Göttingen, Vandenhoeck \& Ruprecht.

Køster, Kristian (1866), Det kirkelige Vennemøde i Kjøbenhavn 10de og 11de September 1866, Kjøbenhavn, Karl Schønberg.

Kaae, Lars (1986), "Ikkun som voxne Menneske-Børn: Grundtvig og frihed” i Tønnes Bekker-Nielsen m.fl. (red.), Stykkevis og delt, Aarhus, Antikva, 75122.

Larsen, E. L. (2012), Frihed for Loke saavelsom for Thor: N.F.S. Grundtvigs syn på andelig frihed $i$ historisk og aktuelt perspektiv. Københavns Universitet, Publikationer fra Det Teologiske Fakultet, Nr. 40.

Lidegaard, Bo (2011), En fortelling om Danmark i det 20. århundrede, København, Gyldendal.

Lindhardt, P.G. (1964), Grundtvig, København, Gad.

Lundgreen-Nielsen, Flemming (1992), "Grundtvig og danskheden” i Ole Feldbæk (red.), Dansk identitetshistorie bd. 3, København, Gyldendal.

- (1999), "Løven i buret. Grundtvig i 1848” i Claus Bjørn (red.), 1848 - det markelige år, København, Museum Tusculanum, 127-151.

Lyby, Thorkild C. (1999), "Grundtvig og Rødding Højskole” i Grundtvig-Studier 1999, 65-93.

Michelsen, Knud (1979), "Grundtvig og hans samtids tænkemåde" i GrundtvigStudier 1979, 17-28.

Mortensen, Viggo (1985), "Anmeldelse af Vartovbogen 1984" i Grundtvig-Studier 1985, 85-86.

Munck, Thomas (2014),"Public debate, politics and print. The late Enlightenment in Copenhagen during the years of the French Revolution 1786-1800" i Historisk Tidsskrift 2014/2, 323-351.

Møller, Erik (1950), “Grundtvig 1848-50” i Grundtvig-Studier 1950, 57-95.

Møller, Jes Fabricius (2005), Grundtvigianisme i det 20. arhundrede, København, Forlaget Vartov.

- (2013) "Krogerup-hypotesen" i Garne og Vangshardt (red.), Kontinuitet og radikalisme, København, Forlaget Vartov, 82-93.

- og Ravn, Kim Steen (2014), "Fattigdom og kommaer" i Weekendavisen/Ideer 28. nov. 2014.

- (2014), "Det indskrænkede monarki og teorien om statsmagtens ligevægt" i Historisk Tidsskrift, bd. 93/4, Oslo, 539-564. 


\section{GRUNDTVIGS BETYDNING FOR SAMFUNDET}

Nevers, Jepper (2011), Fra skaldsord til slagord, Odense, Syddansk Universitetsforlag.

Nygaard, Bertel (2011), “Demokratibegrebets gennembrud i Danmark i 1848” i Historisk Tidsskrift 111/1, 37-73.

Nygaard, Bertel (2014), "Fenrisulven sluppet løs” i Slagmark nr. 69, 53-69.

Olsen, G.H. (1794), Opdragelsesvasenet i Danmark, som en af vigtigste Hindringer for National-Oplysningens Fremme, Sorøe, F.H. Lillie.

Pedersen, Finn Stendal (1999), “N.F.S. Grundtvig og socialpolitikken i Den grundlovgivende Rigsforsamling i foråret 1949” i HistorielJyske Samlinger, nr. $1,32-58$.

Pedersen, Kim Arne (2002), “Grundtvig på anklagebænken” i Grundtvig-Studier 2002, 184-251.

- (2004), "Grundtvig om samfundspagt, gensidig frihed og menneskerettigheder i ca. 1840” i Grundtvig-Studier 2004, 14-33.

- (2013), "Grundtvig, det sociale spørgsmål og velfærdssamfundet” i Korsgaard og Schelde (red.), Samfundsbyggeren, København, Anis, 135-163.

- (2014), "Det jødiske folk og folkelighedsbegrebet i 1814-krøniken” i Grundtvig-Studier 2014, 14-63.

Petersen, K. og Petersen, J.H. (red.)(2010), Dansk Velfardshistorie bd. 1, Odense, Syddansk Universitetsforlag.

Pontoppidan Thyssen, A., "Nationalitet og kirke i Danmark og Slesvig-Holsten 1770-1920 med særligt henblik på Grundtvigs betydning” i Grundtvig-Studier 1999, 27-64.

Prutsch, M. (2012), Making sense of constitutional monarchy in Post-Napoleonic France and Germany, Palgrave.

Rerup, Lorenz (1992), "Grundtvigs indflydelse på den tidlige danske nationalisme”, Grundtvig-Studier 1992, 20-32.

Rosendal, H. (1906), Grundtvigs Højskole 1856-1906, Kolding, Konrad Jørgensen..

Seip, Jens Arup (1958), “Teorien om det opinionsstyrte enevelde”, Historisk Tidsskrift, Oslo, 397-463.

Skovgaard-Petersen, Vagn (1985), Danmarks Historie bd. 5, København, Gyldendal.

Skovmand, Roar (1960), Højskolens ungdomstid i breve, bd. I-II, København, Munksgaard.

Stahl, Friederich Julius (1845), Das Monarchische Princip, Heidelberg, Mohr. 


\section{Jes Fabricius Møller}

Thaning, Kaj, "Grundtvig og den grundlovgivende Rigsforsamling" i GrundtvigStudier 1949, 35-73.

Wåhlin, Vagn (1999), "Grundtvigs økonomiske tænkning" i Grundtvig-Studier 1989, 246-304. 